\title{
Approaches and lessons in political career research: Babel or pieces of patchwork?
}

\author{
Enfoques y lecciones en la investigación sobre carreras politicas: \\ ¿Babel o piezas de un mosaico?
}

\author{
MICHELANGELO VERCESI \\ Center for the Study of Democracy \\ Leuphana University in Lüneburg (Germany)
}

\section{Como citar/Citation}

Vercesi, M. (2018). Approaches and lessons in political career research: Babel or pieces of patchwork? Revista Española de Ciencia Política, 48, 183-206. Doi:https://doi.org/10.21308/recp.48.07

\begin{abstract}
Political careers are a classic subject of elite studies. Scholars have sought to understand what affects political profiles and career patterns' formation. However, political career research is characterized by a variety of approaches and explanations, which often do not communicate each other. A framework that integrates existing contributions is lacking, and this undermines the process of accumulation of knowledge. A comprehensive assessment of the literature is necessary in view of this potentially welcomed undertaking. After a conceptual introduction, I provide here a general overview of the approaches used in political career research, classifiable into two main schools. It is stressed their theoretical arguments, methodological strategies, and deficits. The note will provide bases for developing further the research field, by underling epistemological, theoretical, and methodological lessons.

Keywords: political elites, political careers, theoretical approaches, pathways to power, political recruitment.
\end{abstract}

\section{Resumen}

Las carreras políticas son un tema clásico en los estudios de las elites. Los investigadores han intentado entender qué influye sobre los perfiles políticos y la formación de los patrones de carrera. Sin embargo, la investigación sobre las carreras políticas se caracteriza por una variedad de enfoques y explicaciones que con frecuencia no se comunican entre sí. La falta de un marco que integre las contribuciones existentes mina el proceso de acumulación de conocimiento. En vistas de asumir esta tarea, es necesaria una evaluación comprensiva de la literatura. Después de 
una introducción conceptual, se ofrece aquí un panorama general de los enfoques utilizados en la investigación sobre carreras políticas, que pueden clasificarse en dos "escuelas" principales. Se subrayan sus argumentos teóricos, estrategias metodológicas, y carencias. Esta nota de investigación proveerá bases para el futuro desarrollo de este campo de investigación, subrayando lecciones epistemológicas, teóricas y metodológicas.

Palabras clave: elites políticas, carreras políticas, enfoques teóricos, caminos hacia el poder, reclutamiento político.

\section{INTRODUCTION}

Political elites' career pathways are one of the oldest and discussed topics in the social sciences. Over decades, this field has been characterized by several theoretical, methodological, and empirical debates (Best and Higley, 2018). This is no surprise. Investigating why and how politicians reach power provides insights, on the one hand, about political recruitment mechanisms. On the other, it is a prerequisite to know how individual profiles affect public reputation, performances, and leaders' roles in political systems. The outcome may be a better understanding of channels of political representation.

However, elite studies are still scattered into diverse schools and approaches, whose defining traits are blurred and whose ability to communicate with one another remains low. This is detrimental for a genuine advancement of knowledge in the field. I assume that a better definition of the state of the art is a necessary condition to refine and integrate different approaches, in view of a cumulative framework for the analysis as well as for refreshed theory-guided empirical researches. Here, I aim to give a contribution.

It has been observed that "[ $t]$ he concept of political career is [...] a fundamental pillar of the contemporary literature on elite transformations" (Verzichelli, 2018: 585). I consider a career as political inasmuch as it results in the achievement of a political office, irrespective of the "politicalness" of the previous trajectory, and I focus on political careers as dependent variables or outcomes of interest. I conceive of a career as a set "of [educational and] work-related activities and adventures that an individual experiences, perceives, and acts on during lifetime" (Gerber et al., 2009: 304). In this conceptualization, time plays an important role. According to Arthur et al. (1989: 8) as well as Jahr and Edinger (2015: 17), careers should be studied as chains of moves informed by dynamic interactions over time between individuals and environment. Following in Jahr and Edinger's (2015: 12-13) steps, I buy the distinction between an objective dimension of political careers (encompassing occupations and offices held) and a subjective dimension (referring to individual decisions, attitudes, and goals). The career steps of the former dimension can be understood as "career positions" (Martocchia Diodiati and Verzichelli, 2017: 10).

This note deals with political careers in general, without distinguishing between the political offices individuals can reach. This is why explanations of political careers provide some basic theoretical arguments that can be applied to different situations. 
The idea, for example, that personalities or institutions affect career outcomes holds both for elected and non-elected political offices; what changes is probably the way they do it, given the position of interest. However, because of the disparity of attention to different political positions, most of the literature refers to national and sub-national MPs and ministers, with some exceptions, such as works dealing with national executive leaders and supranational institutions (e.g., the European Parliament). ${ }^{1}$

Two "schools" of political career research stand out: "actor-" and "context-oriented" (Jahr and Edinger, 2015: 13-14). While the former focuses on individuals, the latter stresses the role of contexts as explaining factors. In the next two sections, I critically review the relevant literature. Subsequently, I try to wrap up the main epistemological, theoretical, and methodological lessons we can draw for integrating existing insights. The final part stresses the points of contacts from where to start for further developments and possible research outlooks.

\section{AGENCY AND POLITICAL CAREERS: ACTOR-ORIENTED APPROACHES}

The most classic approach is perhaps the biographical account. The underlying idea is that the reasons of success can be detected in previous personal experiences. The roots of leaders' achievements have often been assumed to lie in the childhood or in primary socialization periods.

Biographies' reliability is by definition limited, due to the role that subjective interpretation plays. However, "biography works by analogy and inference rather than empiricism alone" (Walter, 2014: 317). Some biographical studies provide both heuristic typologies and theoretically informed accounts of political careers: in this regard, psychobiography plays a significant role (Post, 2013; Walter, 2014: 320-321). At the intersection between psychology and political science, some scholars have sought to find nexuses between family histories and political achievements (Hudson, 1990; Andeweg and Van Den Berg, 2003).

An empirical weakness is that it is hard - if not epistemologically mistaken- to draw generalizations from individual experiences (Haslam et al., 2011: 11-12). Moreover, we are forced to deduce that unsuccessful careers are simply consequences of a lack of experience or personal traits (Haslam et al., 2011:14). The personality approach has tried to go beyond this pitfall, addressing Greenstein's (1969: 47) question about "actor dispensability": "[u]nder what circumstances do different actors (placed in common situations) vary in their behavior and under what circumstances is their behavior uniform?".

1. In this work, the literature on career steps outside politics, such as in bureaucracy will be mentioned only in case it provides argumentations to explain future achievements of proper political offices. 
The personality approach posits that individuals' own personalities affect career paths. Jahr and Edinger (2015) have traced back the origins of the personality approach to Machiavelli. However, this approach entered the age of scientific maturity only in the twentieth century, especially with Lasswell's writings (Lasswell, 1948). Later comparative works have clustered personality's characteristics into trait factors, while typologies have been used as heuristic tools (Caprara and Silvester, 2018).

The personality approach presents the problem of how to measure personal traits. One option is survey analysis, while diagnoses and theory-based ratings based on biographical analysis play a prominent role as alternative methods. A third research strategy is content analysis of speeches, interviews, and documents (Winter, 2013: 429-431). Whereas the difficulty of coping with at-a-distance analyses of single politicians can be the main methodological concern (e.g., Greenstein, 1969: 127-139; Schafer, 2014), the potential un-contextual nature of the investigations on personalities is an issue of theoretical relevance (Haslam et al., 2011: 13). Attempts to combine psychological attitudes and social context are pursued by the ambition theory approach.

The first systematization of ambition theory is path-breaking Schlesinger's (1966) Ambition and Politics. In his monograph, Schlesinger claims that politicians are ambitious social actors, who aim at particular political offices. One can find "order in the careers" and "reasonable expectations for national advancement are not scattered at random" (Schlesinger, 1966: 36). Black (1972) suggests that personal ambitions are susceptible to changes, depending on the followed career path. This means that ambition is not only a by-product of politicians' psychologies, but it also depends on the institutional role they perform. Further bricks to the theory have been added for example by Nicholls (1991), Herrick and Moore (1993), Hall and van Houweling (1995), Lawless (2012), and Öhberg (2017).

A first empirical strategy is to use actual behavior as a proxy of ambition. Politicians' ambition is measured or simply classified by observing the positions individuals have held in their careers up to a certain point. The assumption is that differences ensue from different ambitions. A major problem is that ambitious people who have decided not to run or have not achieved the hoped office for whatever reason are not counted in the analysis. Direct surveys and interviews are alternative strategies that can limit this problem (Maestas, 2003; Lawless, 2012). Nonetheless, "we cannot be sure to what extent the attitudes [... interviewees] state are actually translated into behavior. Furthermore, these measures suffer from the usual problems of [...] surveys" (Sieberer and Müller, 2017: 30-31). Both methodologies suffer from the difficulty of generalizing, based on actual behaviors or circumscribed samples (Hibbing, 1993: 120-121). Finally, Jahr and Edinger (2015: 15-16) observes that it is hard to take for granted that there is always an evident hierarchy of offices and that politicians do not aim at lower positions, even for rational/ instrumental reasons.

By positing that similar backgrounds and socializations are likely to lead to similar career outcomes, the social background and socialization approach considers psychology as a fixed or secondary factor. The main independent variable becomes the 
individual background, not specific personal traits. As a result, the room for maneuver for generalizations grows.

The approach posits that "the chances of reaching a political office [...] are not spread equally across various strata of society" (Jahr and Edinger, 2015: 16). Individuals (may) move from their current position to another, once they have reached a certain amount of resources of expertise (ibid.: 17). On the one hand, the approach tells that certain types of socio-economic status and/or career trajectory are likely to affect further career steps. For example, political elites are traditionally male, with a higher socio-economic status, and well-educated (Putnam, 1976; Bovens and Wille, 2017; Gaxie, 2018). Moreover, they are used to reach higher political offices after acquiring some political expertise at lower levels and following paths of political professionalization (Blondel and Thiébault, 1991; Allen, 2013; MacKenzie, 2015; Müller-Rommel and Vercesi, 2017). On the other hand, family environments, political organizations and political institutions where individuals "learn and live" politics affect politicians' preferences and attitudes towards career paths (Searing et al., 1973; Mughan et al., 1997; Scully, 2005; Beauvallet-Haddad and Michon, 2010; Pilet et al., 2014; Daniel, 2015).

Data are mostly gathered through official documentation and interviews; however, the range of knowledge is circumscribed. Surveys can help to overcome the problem, but they are usually limited in their scope and do not highlight elite networks (Hoffman-Lange, 2007). Network analyses observe previous individuals' relationships with other politicians or people in other public and private sectors. This allows getting insights about elites' internal cohesion and differentiation; moreover, one can speculate about the effect of networks on prospective career chances. A more formalized method is sequence analysis. By clustering political careers based on sequences of held positions, this method distinguishes between career patterns and provides information about the impact of different trajectories on the achievement of political offices. Sequence analyses take in consideration also the duration and order of services in each career position (e.g., Real-Dato and Alarcón-Gonzáles, 2012; Jäckle, 2016; Ohmura et al., 2018). Two main deficits have been highlighted: (1) the effect of overlapping jobs is hard to disentangle; (2) the test of third explanatory variables is not as viable as it is with (deductive) longitudinal regression models (Jäckle and Kerby, 2018).

Whatever the methodology is, the social background and socialization approach misses the fact that

a considerable number of people from [...] even lower social strata manage to reach political top positions. [...] Second, the focus on social background completely ignores the individual as the "architect" of his or her own career, who at some point decides whether to opt for the political career track or not (Jahr and Edinger, 2015: 17).

Actors' freedom of choice is taken into account by the selection and deselection approach. This approach rearranges biographical data for deductive - rather than inductive - theories. The core of the argumentation is the reason why party and 
institutional gatekeepers select specific figures to occupy political posts, with a shift from the "personal" to the institutional role one occupies. The selection and deselection approach is, thus, a kind of theoretical bridge between actor- and context-oriented approaches. It is based on the principal-agent theory of political relations and the impact of agency on political outcomes is derived from some basic assumptions about the nature of individuals' political role (e.g., Searing, 1991). The theory posits that political positions are filled by principals who select prospective agents for this; agents are supposed to behave as the principal wants. Principals may screen agents before (ex-ante screening) and after (ex-post screening) the selection (Dowding and Dumont, 2015). What is particularly interesting for career research is the ex-ante screening process, as shown for example by the pioneering Hubert and Martinez-Gallardo's (2008) study on ministerial stability. Principals could prefer an agent with a specific experience rather than others. In addition, institutional factors may affect the choice (Dowding and Dumont, 2009; Samuels and Shugart, 2010; Grimaldi and Vercesi, 2018). The overall assumption is that, all else equal, different individuals occupying similar political offices will select (and deselect) individuals with similar professional profiles, irrespective of their own personal preferences. A common measurement of experience and performance in office is individual tenure (e.g., Berlinski $e t$ al., 2012; Fischer et al., 2012; Bright et al., 2015).

If one excludes a few QCA exceptions (Fisher et al., 2006), the selection and deselection approach is mostly related to event-history and duration models. These methods are well-equipped for statistical tests of explanatory variables' net effects, more than sequence analysis. However, a major problem is that these methods are relatively static and can only account for single career passages (Jäckle, 2015; Jäckle and Kerby, 2018); in other words, these models focus on events and not on career trajectories. They account for "how the duration spent in one social state affects the probability some entity will make a transition to another social state" (Box-Steffensmeier and Jones, 1997: 1414). A more general deficit is that contextual factors are taken in consideration only in terms of expectations about party and institutional roles, without paying the due attention to other structural factors.

Before moving to the next section, table 1 summarizes the main points I have addressed.

\section{STRUCTURE AND POLITICAL CAREERS: CONTEXT-ORIENTED APPROACHES}

The opportunity structure approach posits that ambitious politicians assess career opportunities when they choose a career path rather than another. Theoretically, this leads to an overturning of the causal arrow: structures affect individual decisions, not vice versa. According to Borchert (2003), the opportunity structure is determined by the availability (how many), accessibility (how much easy they are to reach), and attractiveness (what they provide in terms of prestige, material benefits, skills, etc.) of 


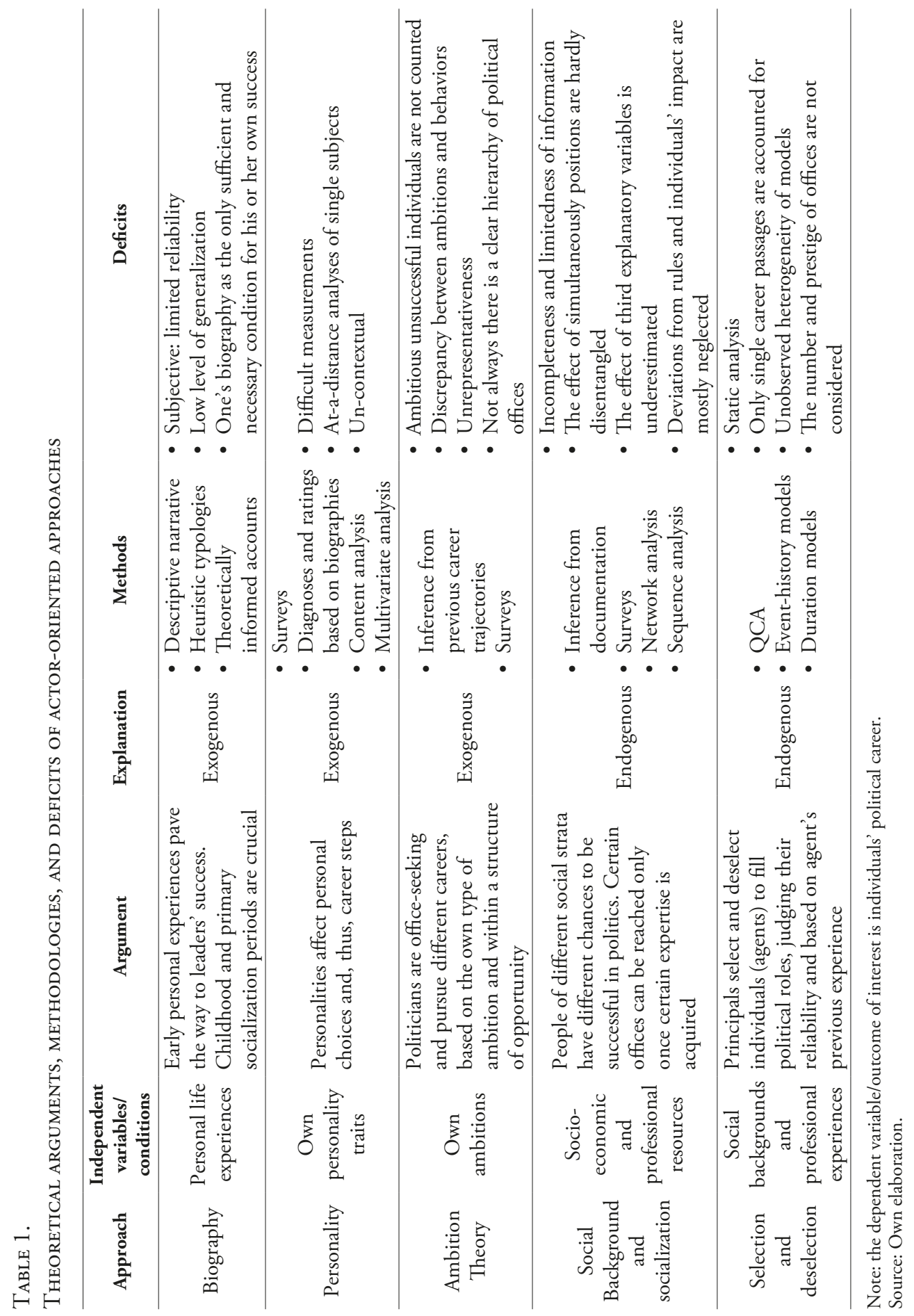


political offices. Scholars from the opportunity structure approach argue that career paths in multi-level systems adhere to a few ideal-type models (Botella et al., 2010; Borchert, 2011; Stolz, 2001, 2003, 2015; Stolz and Fischer, 2014; Grimaldi and Vercesi, 2018). Scholars also stress the role of electoral rules in defining political posts' accessibility (Siavelis and Morgenstern, 2008; Jun and Hix, 2010; Carreras, 2012).

The approach is characterized by either single-country studies (e.g., Stolz and Fischer, 2014; Grimaldi and Vercesi, 2018) or small-N qualitative comparisons (e.g., Botella et al., 2010; Stolz, 2010). However, truly comparative assessments under a common analytical framework have been provided (e.g., Borchert and Stolz, 2011; Edinger and Jahr, 2015).

A potential pitfall is highlighted by the literature on educational and career choices: determinism. Hodkinson and Sparkes (1997: 39-40) underline that career decisions are taken within structural contexts and based on on-going interactions. These authors conceive of career developments as sets of turning-points, whose predictability can vary according to structural constraints and personal room for maneuver. Between turning-points, there are "routine" periods, during which individuals can change their own career identities and prospective. This is important to explain why similar previous goals and political experiences can result in different future career decisions. A second deficit is the lack of attention for the internal procedures of political organizations and institutions.

In this regard, the intra-organizational approach focuses on the organizational drives that channel career patterns. Organization and management studies tell that organizational features limit individuals' options and steer career choices within narrower ranges (e.g., Dalton, 1989: 94): "organization type may moderate the relationship between the $[\ldots]$ external career concerns and the employment of networking tactics" (Zanzi et al., 1991: 230). While the opportunity structure approach looks at structural conditions from a systemic viewpoint, the intra-organizational one focuses on single organizations and their internal life. In other words, attention is payed to how formal and informal organizational rules and procedures affect career choices, given broader career opportunities provided by the political system as a whole. Intra-organizational features would have an impact on role expectations (Abrutyn 2014: ch. 4).

Several scholars underline the impact that party organizational forms and intraparty behavior may have on career trajectories (e.g., Thurber, 1976; Hazan and Rahat, 2010). Norris (2006: 92) claims that the breadth of career choices is shaped by three factors: (1) the centralization of the internal nomination process; (2) the level of participation in nominations; (3) the scope of the decision-making process. Based on these, ambitious politicians change career strategies and perceptions of the own political role (e.g., Dudzińska et al., 2014). Additional works falling into the intra-organizational category may be found among legislative studies, according to which the internal division of labor of modern parliaments fosters MP's specialization and the development of different professional skills (e.g., Judge, 1981; Hall and Grofman, 2014). Moreover, bureaucratic studies have stressed that variations in the 
organizational features of bureaucratic apparatuses are conducive to different material and non-material incentives for those interested in pursuing a career in politics. This means, for instance, that people with similar ambitions can be pushed to make different strategic choices, based on existing appointment methods in bureaucracy (Peters, 2010: 82-85, 97-107).

In addition to descriptive statistics, intra-organizational studies employ regressional analyses: organizational rules, procedures and structures are the main independent variables.

These methods are functional to answer the relevant research questions. However, the approach is too narrow to study career trajectories from broader perspectives. The effects of structural features are studied only as long as people are parts of the organizations at issue, and external networks and features of political systems are neglected. If, on the one hand, the opportunity structure approach is sometimes too generic, the intra-organizational approach suffers from the opposite shortcoming, being too specific. In addition, empirical studies do not look at different concurrent organizational memberships. It is also worth noting that the empirical evidence highlights that broader contextual factors are more important than intra-organizational factors in shaping politicians' careers (Grimaldi and Vercesi, 2018: 144). For large comparative studies, the opportunity approach thus seems more fruitful. Nonetheless, the choice ultimately depends on the own research question and the focus of interest. However, an explanatory aspect that both approaches overlook is the interplay between the availability of potential politicians and the actual societal demand.

The supply and demand approach primary looks at individuals. Yet, it can be classified as a context-oriented approach because it deals with people and social behaviors in macro terms, as aggregates, and observes those social tendencies that constrain individual behaviors. The question is why some sectors of the society enter political offices more than other. We have seen above that, in the selection and deselection approach, the focus is on the relationship between principals and agents, who are understood based on their institutional role (for example, why does a prime minister prefer some ministerial profiles in the own cabinet?). The idea is that an agent is selected because of his or her reliability and loyalty. The supply and demand approach is different: scholars are interested in detecting structural trends and variations in the representation of social groups. In this case, attention is especially paid to barriers to enter given political posts. Usually, scholars study women's political representation; however, the basic arguments can be easily extended to other societal segments (e.g., Norris and Lovenduski, 1995; Carnes 2016; Gouglas et al., 2018; Pansardi and Vercesi, 2017). Krook (2010: 708) summarizes the approach's assumptions by describing political careers as a step-by-step process. First, from the larger number of eligible people to the smaller portion of those who want to get a political office; second, from ambitious people to a smaller group of selected by gatekeepers; finally, from selected people to the narrow circle of citizens who actually reach political offices. Successful careers would be the result of the interaction of the supply of individuals, which determines the passage from the first to the 


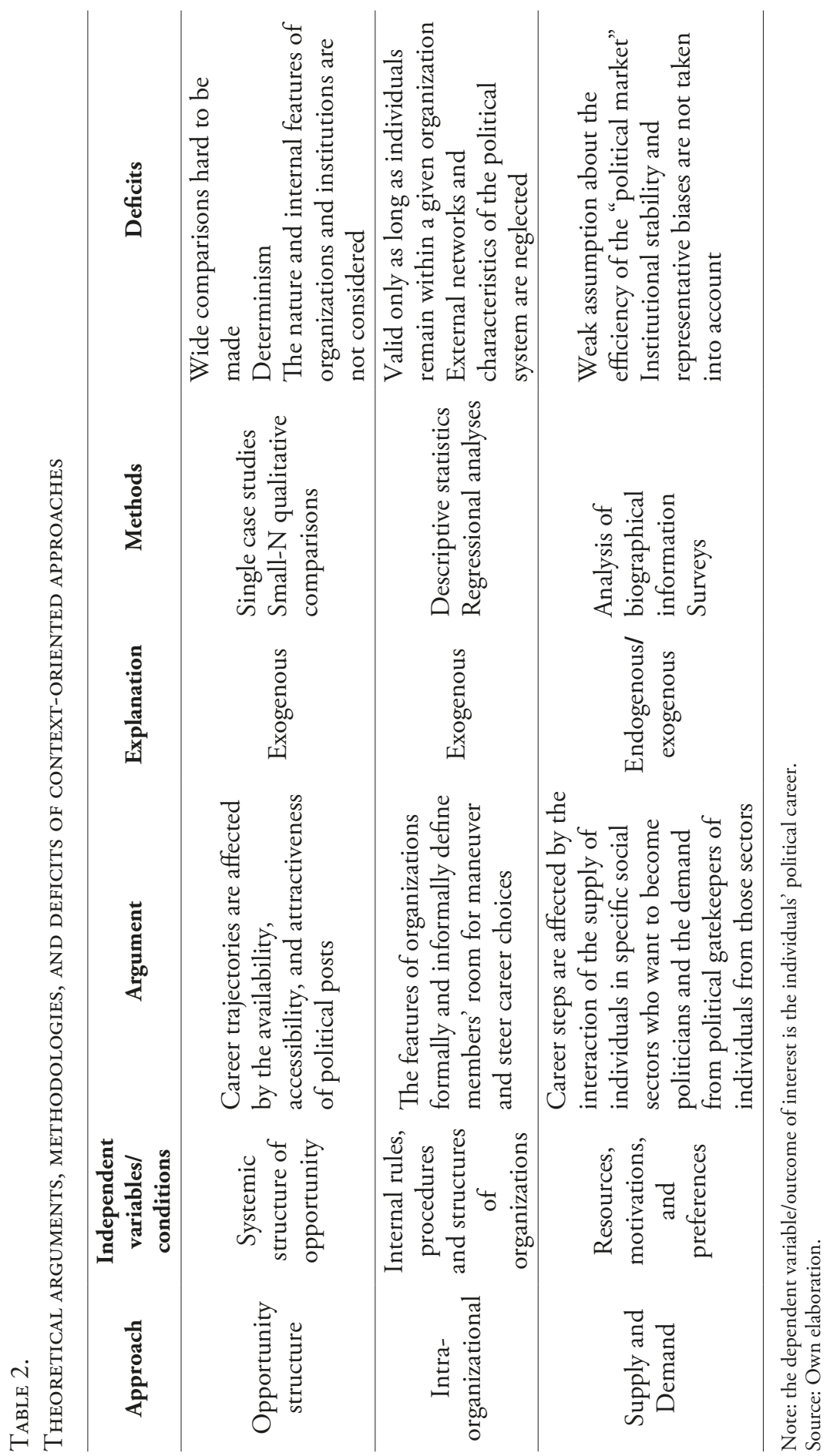


second step, and the demand of prospective politicians, which shapes the passage from step two to step three. According to Norris and Lovenduski (1993), supply depends on (material and intangible) individuals' resources and motivations, whereas elites' preferences work as gatekeeping factors.

In the studies of the supply and demand approach, the dependent variable is usually operationalized as the numerical presence of people from a certain social (often a minority) group occupying political offices. Proxies of motivations and resources are, instead, socio-economic characteristics, political ambition, personalities, dispositions and political experience (e.g., Norris and Lovenduski, 1993). Data on gatekeepers' preferences can be collected by means of the submission of surveys. Information is then processed through both descriptive statistics and regression analyses (e.g., Norris and Lovenduski, 1993).

Krook (2010) underlines that supply-demand studies implicitly posit that political careers develop within an efficient "political market", where the outcome is provided by the match of supply and demand. However, this assumption cannot account for the presence of recurring patterns of under and overrepresentation of certain groups in different societies. Institutional stability is indeed likely to lead to self-reinforcing patterns, irrespective of societal changes; moreover, cultural traditions can create distortions between the two sides of the "market". Thus, Krook (2010) proposes understanding representational biases as the combination of systemic, practical, and normative institutions. "Institutionalism may [...] offer new tools for capturing dynamics of continuity and change and [...] help structure [...] findings in a way that better highlights their contributions" (Krook, 2010: 717).

Table 2 provides an overview of the context-oriented approaches.

\section{TOWARDS AN INTEGRATED APPROACH? LESSONS FROM THE LITERATURE}

At first glance, the picture emerging from this broad review looks like a chaotic set of approaches, methodologies and findings, which are hardly connected or even in conflict with one another. However, a painstaking granulation process of the insights can reveal much more than this. The multiplicity of approaches in career research provides different perspectives to read the same reality. These perspectives are not mutually inconsistent, rather they are complimentary. In particular, I claim that scholarship provides several useful lessons that could be followed in view of new and more comprehensive approach.

Between the wrinkles of the uneven literature I have analyzed, it is possible to find tentative but fruitful suggestions to study paths to power within a new general framework. The lessons we have learned may be distinguished between "positive" and "negative". While the former refer to those achievements that we should not discard, the latter basically concern the main deficits of the various approaches. Moreover, we can 
group these lessons into three main categories: epistemological; theoretical; and methodological. ${ }^{2}$ I summarize them, following this sequence.

\section{Epistemological Lessons}

The main epistemological lessons concern the type of causal effects that given factors have on political careers and the possibility to make inferences and generalizations from a set of observations.

A first remark is that we should avoid any deterministic conclusion, when it comes to investigate pathways to power. Structural factors, for example, can be very important in establishing the constraints and opportunity people face along their career. However, the room left for maneuvering is large enough to grant prospective politicians the necessary freedom to define their career steps through their own decisions. To put it differently, individuals with similar ambitions and operating in the same environment can be more or less successful, because of different personal choices and strategies. Here comes the debate about the determinants of individual choices. In this regard too, determinism can be an epistemological pitfall. Especially naïve biographi$\mathrm{cal}$ and personality-based studies risk concluding that politicians' paths to power are inscribed within the very nature of the individual politician. However, we have seen that personalities are made up of several traits; how these traits mix and interact with circumstances and unpredicted events can lead to alternative outcomes, given equal starting points. Different contextual factors can make the destiny of two or more individuals with similar ambition and resources diverge. Symmetrically, personal orientations and aims may decide the success or failure of different politicians within the same opportunity structure. Several factors seem to be likely to shape political careers at the same time; moreover, none of them looks definitely overwhelming compared to others. This leads to a further crucial observation. If we accept these statements, then we will have to admit that careers are to be explained as the outcomes of a configurational "twist" of factors. Some of these factors can be more or less important, depending on variations of third conditions (e.g., Baumgartner, 2009).

The second issue to touch upon is the hurdle one meets when s/he wants to generalize, based on a few individual experiences, especially on lives of prominent leaders. I have mentioned Greenstein's idea of “actor dispensability". This can be a key to overcome the problem. Generalizations would come by looking at the degree of variation of personal behaviors and experiences - which can be translated as the variation of career choices and steps - within the same socio-political context. ${ }^{3}$ In this way, we

2. Due to this note's perspective, I do not mention possible empirical lessons. This would require a further analysis of literature's findings, which is out of the scope of this work.

3. When it comes to study only successful politicians, it is not possible to assess possible mistakes of evaluations in the strategies of 'failed' ambitious individuals. As the opportunity structure 
could generalize about how individual factors can have an impact on careers, given an opportunity structure. The hoped result would be both the avoidance of structural deterministic argumentations and a due focus on agential influences, without falling into insidious micro-level explanations (e.g., Hodgson, 2007).

To summarize, the first two lessons are as follows. (1) Agency does matter and its impact should not be discarded. However, individuals should be conceived of as social actors constrained by environmental structures. This would happen in a non-deterministic way and within configurational combinations of systemic and practical conditions. (2) Generalizations can be made by recognizing the explicatory priority of contextual factors over agential forces. However, agency plays a significant role in determining career choices and advancements within the maneuver margin left by structural conditions.

\section{Theoretical Lessons}

Once assessed the epistemological standpoint that is more useful to tackle the distinction between structure and agency, ${ }^{4}$ we can now extract more specific theoretical lessons about their actual interplay. Personality and ambition theory approaches tell us that personal psychological inclinations can affect personal choices. One assumption I buy is that politicians are ambitious social actors. If one deals with top politicians, it can be assumed, for example, that the actors at issue are rational office-seeking politicians with a progressive ambition. This would solve the aforementioned methodological problem of how to measure ambition of successful politicians, in comparison with those who have not achieved the hoped office: simply, this goes outside the horizon of the scope of possible researches on prominent political figures.

One very important implication of the ambition assumption is that careers are not shaped by chance. There is a certain order behind them, since individuals with similar ambitions would tend to behave in similar ways, if put in similar contexts. However, we have also learned that personal attitudes towards power are not fixed; rather, they can change during life time, depending on the fulfilled institutional roles and the organizations one operates in. Institutions shape the choice of the sequence of career steps. Both public and private sectors can be of service to reach the political office of destination. The consequence of this reasoning is that significant variations among possible routes to power are likely to occur, even if all eventually lead to a given

approach implicitly suggests, we can easily assume that prospective or current politicians are rational actors when they take their decisions along their career paths. In this case, the assumption would not refer to their actual nature; rather it would operate as a methodological indicative principle.

4. I do not enter any thorny discussion about the ontological considerations that are implied in this dualism (e.g., Archer, 2003). I simply refer to the bases of explanations, not to the 'nature' of reality. 
position. In a nutshell, there is more than one rational option available to obtain the same outcomes. This is not to say that some educational and professional backgrounds are not more valuable to reach a post; however, the way and the gradients in which these personal resources combine may vary. Finally, one could notice that the studies based on the ambition theory stress that personalized contexts push people to pursue personal visibility.

As I have already noted, considerations about personal traits and experiences at aggregate level prompt to contemplate individuals as holders of specific formal or informal roles. This perspective helps build deductive theories about the relationship between the supply of ambitious politicians (an aspect that can be considered fixed in particular comparative studies) and the demand made by principals.

However, how do structural factors impact on these processes, according to the literature? The basic arguments of the opportunity structure approach provide potentially insightful suggestions. Ambitious politicians and personal networks are favored or constrained by environmental conditions. Thus, we can use actor-oriented explanations to account for variabilities in similar contexts, only after assessing the structural conditions of the picture. The scholarship argues that politicians are aware of the structural limitations they have to cope with along their paths to power. These limitations can take the shape of systemic career opportunities as well as of rules and procedures in organizations and institutions; the former logically forerun the latter. Organizational and institutional drives can lead eventually to some forms of specializations rather than others.

Finally, important theoretical lessons from the supply and demand approach are that in different societies there can be a tendency to value more some personal backgrounds compared to others. However, changes over time are possible; in this respect, an institutionalist perspective can be an appropriate lens to read the drives behind this phenomenon.

Overall, we have therefore been told that (1) systemic opportunities (macro-level) define the picture within which individuals — rational, ambitious, and office-seeking - take career decisions and value certain profiles (micro-level). Organizations and institutions (meso-level) impact on individual strategies, by mediating between macro and micro forces. (2) The range of alternatives about the selection of politicians is limited by the contingent context. Selection biases tend to reproduce themselves over time; however, more or less sudden changes can modify the situation and lead to inter-elite circulation.

\section{Methodological Lessons}

Career research employs a variety of methods. These oscillate from strictly qualitative to strictly quantitative methodologies, proposing several research tools and heuristic devices. I have already assessed their goodness for the pursued goals of each approach. Here, I do not need to go back to the whole debate. On the 
contrary, I try to highlight only a few guiding suggestions that can be useful for further analyses, according to the aforementioned epistemological and theoretical considerations.

One very basic reflection based on the difficult generalization of some actor-oriented studies is that large- $\mathrm{N}$ comparisons — either longitudinal or cross-sectionalcan be a valuable way to reach sturdier results. The need of higher numbers of individual cases for the analysis is well displayed — for example — by the scholarship on women executives: the more women have attained authority positions, the more scholars have been able to provide stronger findings and more convincing theoretical arguments (e.g., Jalalzai 2013).

Needless to say that independent variables and conditions to explain political careers stem from the chosen theoretical perspective and the very topic of interest. However, the outcome at stake - that is, pathways to power and politicians' profiles - is given. The question, thus, becomes how to operationalize it, but also how to treat it methodologically. We have seen that political careers can follow very different tracks; they can be informed by myriad combinations of career positions and by several possible sequences of steps. In this regard, the literature has compellingly shown how the construction of a few ideal-types is a fruitful way to systematize differences. The social background and socialization approach is perhaps the clearest contributor in this respect, being the distinction between political insiders and outsiders nothing but one major example of such shortcuts. However, even biographical and personality-based accounts have, for example, resorted to typologies to classify politicians. Overall, grouping politicians we are interested in into some theoretically derived types based on career profiles seems a viable solution to deal with careers' complexity in view of explanatory investigations.

I have mentioned that career types are often associated to the employment of sequence analyses. However, I have also claimed that this research strategy does not account, on the one hand, for the effects of third variables other than career steps and, on the other hand, for the possible additive impact of the concomitant occupation of two or more job positions. Similarly, we have seen that event-history analyses can pay the due attention to career modifications from time to time only, without any integration in a less fragmented framework. In contrast, one could seek to broaden the perspective, including encompassing considerations of careers over longer time, especially when it comes to explain politicians' career trajectories on the whole. I think that the acknowledgements of these shortcomings can be considered as further lessons to start from to develop a methodological setting useful for career research. This does not mean discarding the potential benefit of classic regression arguments to explain the selection of prominent politicians or the connections between specific offices and subsequent career steps. Rather, the insights could be placed within broader structural considerations of opportunities and constraints.

I try to sketch some suggestions: (1) the multiplicity of potential paths to power can be fruitfully summarized and reshaped into a limited number of politicians' types, derived by their educational and professional profiles; (2) large- $\mathrm{N}$ samples can help 
both have reliable validations of the correspondence between ideal-types and real world cases and provide ground for sturdier generalizations; (3) we should aim at a methodology that allows combining accounts of personal career changes with holistic explanations of the relationship between structures and individual behavior in aggregate terms.

\section{CONCLUSIONS}

We have seen that several strands of the literature argue that individuals do matter and, therefore, we should avoid deterministic structural views. Moreover, we have seen that, for the sake of generalization, the focus on agency should be on institutional roles, rather than individuals per se. In this regard, the selection and deselection approach provide a viable conceptual background. A third observation is that there are good reasons to assume that pathways follow stable patterns and institutionalized logics. However, we know "that a lengthy phase of elite stability [...] is now over and that many factors capable of accelerating the pace of elite circulation are emerging in traditional Western democracies, as well as in other and newer democratic contexts around the world" (Verzichelli, 2018: 585-586).

A new comprehensive approach for the explanation of political careers should account for deep social changes. This could imply combining pathway stability with the role of gatekeepers in the reshape of patterns during junctural modifications of representational channels. Political careers could be affected by path-dependent dynamics. However, these drives could be likely to change in periods of broader societal renewals. The approach could be also a viable way to address some open issues in political career research, such as the juxtaposition between institutional and goal-driven perspectives on careers or the development of multi-level careers, which I have only touched upon. Indeed, "[t] he first task of a [...] theory of [political] careers [... remains] to identify interests and to explore how and why they have come to be defined as they have" (Pfeffer, 1989: 392). Multi-level settings, on their turn, would be nothing but further sources of opportunities and constraints strategic actors with own interests respond to (Jahr and Edinger, 2015: 9-10).

In this regard, a further element could be introduced in future comparative analyses: the conditional role of country factors and regime types. I have only mentioned this issue briefly because my interest was to focus only on causal directions and nexuses, broadly enough to provide lessons able to travel across time and space. However, country-oriented elite research on European countries (e.g., Herzog, 1975; Birnbaum, 1977; Cotta, 1979; Fettelshoß, 2009,) and other areas (e.g., Vommaro and Gené, 2018) have shown that the same democratic elites can follow distinct paths to power, depending on the political system where they are formed. Moreover, recent data about political leaders' profiles in democracies and autocracies have been collected. It has been observed that democratic leaders differ from leaders in autocratic regimes and 
that there are also significant variations between autocracies (Baturo, 2016). These findings eventually prompt us to include country factors in explanations of political careers, yet within the approach I suggest here.

The literature on political career research offers several sparks for a more integrated approach. Rather than impervious to mutual talks, the analyzed approaches look like pieces of a more general picture, each focusing on specific aspects and neglecting others. The next step could be to try to put these pieces together. As said in the introduction, I am confident that a critical overview of the existing contributions will be able to facilitate this intellectual operation.

\section{ACKNOWLEDGEMENTS}

I am grateful to Ferdinand Müller-Rommel for his suggestions and comments on an earlier draft of this note. Extended versions of part of this work were presented at the "Redefining Political Sociology" conference at the Andrés Bello University (Santiago de Chile, 11-13 December 2017) and at the "Jean Blondel Tuesday Seminar" of the Department of Social, Political, and Cognitive Sciences of the University of Siena (Siena, 27 March 2018). I thank the participants and especially Stéphanie Alenda and Maurizio Cotta as well as two Revista Española de Ciencia Politica's anonymous reviewers for comments and suggestions.

\section{References}

Abrutyn, Seth. 2014. Revisiting Institutionalism in Sociology: Putting the "Institution" Back in Institutional Analysis. New York: Routledge.

Allen, Peter. 2013. "Linking Pre-Parliamentary Political Experience and the Career Trajectories of the 1997 General election Cohort", Parliamentary Affairs, 66 (4): 685-707. Available at: https://doi.org/10.1093/pa/gss030.

Andeweg, Rudy B. and Steef B. Van Den Berg. 2003. "Linking Birth Order to Political Leadership: The Impact of Parents or Sibling Interaction?”, Political Psychology, 24 (3): 605-623. Available at: https://doi.org/10.1111/0162-895X.00343.

Archer, Margaret S. 2003. Structure, Agency and the Internal Conversation. Cambridge: Cambridge University Press. Available at: https://doi.org/10.1017/ CBO9781139087315.

Arthur, Michael B, Douglas T. Hall and Barbara S. Lawrence. 1989. "Generating New Directions in Career Theory: The Case for a Transdisciplinary Approach", in Michael B. Arthur, Douglas T. Hall and Barbara S. Lawrence (eds.), Handbook of Career Theory. Cambridge: Cambridge University Press. Available at: https://doi. org/10.1017/CBO9780511625459.003.

Baturo, Alexander. 2016. "Cursus Honorum: Personal Background, Careers and Experience of Political Leaders in Democracy and Dictatorship. New Data and 
Analyses", Politics and Governance, 4 (2): 138-157. Available at: https://doi. org/10.17645/pag.v4i2.602.

Baumgartner, Michael. 2009. "Inferring Causal Complexity", Sociological Methods and Research, 38 (1): 71-101. Available at: https://doi.org/10.1177/0049124109339369.

Beauvallet-Haddad, Willy and Sébastien Michon. 2010. "Professionalization and Socialization of the Members of the European Parliament", French Politics, 8 (2): 145-165. Available at: https://doi.org/10.1057/fp.2010.6.

Berlinski, Samuel, Torun Dewan and Keith Dowding. 2012. Accounting for Ministers. Scandal and Survival in British Government 1945-2007. Cambridge: Cambridge University Press. Available at: https://doi.org/10.1017/CBO9780511980046.

Best, Heinrich and John Higley (eds.). 2018. The Palgrave Handbook of Political Elites. Basingstoke: Palgrave Macmillan. Available at: https://doi.org/10.1057/978-1137-51904-7.

Birnbaum, Pierre. 1977. Le sommets de l'Etat. Essai sur l'élite du pouvoir en France. Paris: Editions du Seuil.

Black, Gordon S. 1972. "A Theory of Political Ambition: Career Choices and the Role of Structural Incentives", The American Political Science Review, 66 (1): 144159. Available at: https://doi.org/10.2307/1959283.

Blondel, Jean and Jean-Louis Thiébault (eds.). 1991. The Profession of Government Minister in Western Europe. Baingstoke: Macmillan. Available at: https://doi. org/10.1007/978-1-349-11395-8.

Borchert, Jens. 2003. "Professional Politicians: Towards a Comparative Perspective", in Jens Borchert and Jürgen Zeiss (eds.), The Political Class in Advanced Democracies: A Comparative Handbook. Oxford: Oxford University Press. Available at: https://doi.org/10.1093/0199260362.003.0001.

Borchert, Jens. 2011. "Individual Ambition and Institutional Opportunity. A Conceptual Approach to Political Careers in Multi-level Systems", Regional and Federal Studies, 21 (2): 117-140. Available at: https://doi.org/10.1080/13597566.2011.529757.

Borchert, Jens and Klaus Stolz. 2011. "Moving through the Labyrinth: Political Careers in Multi-level Systems", Regional and Federal Studies, 21 (2): 107-115. Available at: https://doi.org/10.1080/13597566.2011.529756.

Botella, Joan, Juan Rodríguez Teruel, Oscar Barberà and Astrid Barrio. 2010. "A New Political Elite in Western Europe? The Political Careers of Regional Prime Ministers in Newly Decentralised Countries", French Politics, 8 (1): 42-61. Available at: https://doi.org/10.1057/fp.2009.40.

Bovens, Marck and Anchrit Wille. 2017. Diploma Democracy. The Rise of Political Meritocracy. Oxford: Oxford University Press.

Box-Steffensmeier, Janet M. and Bradford S. Jones. 1997. "Time Is of the Essence: Event History Models in Political Science", American Journal of Political Science, 41 (4): 1414-1461. Available at: https://doi.org/10.2307/2960496.

Bright, Jonathan, Holger Döring and Conor Little. 2015. "Ministerial Importance and Survival in Government: Tough at the Top?", West European Politics, 38 (3): 441-464. Available at: https://doi.org/10.1080/01402382.2014.993166. 
Caprara, Gian Vittorio and Jo Silvester. 2018. "The Personality Attributes of Political Elites", in Heinrich Best and John Higley (eds.), The Palgrave Handbook of Political Elites. Basingstoke: Palgrave Macmillan. Available at: https://doi.org/10.1057/ 978-1-137-51904-7_30.

Carnes, Nicholas. 2016. "Why Are There So Few Working-Class People in Political Office? Evidence from State Legislatures", Politics, Groups, and Identities, 4 (1): 84-109. Available at: https://doi.org/10.1080/21565503.2015.1066689.

Carreras, Miguel. 2012. "The Rise of Outsiders in Latin America, 1980-2010”, Comparative Political Studies, 45 (12): 1451-1482. Available at: https://doi. org/10.1177/0010414012445753.

Cotta, Maurizio. 1979. Classe politica e parlamento in Italia, 1946-1976. Bologna: Il Mulino.

Dalton, Gene W. 1989. "Developmental Views of Careers in Organizations", in Michael B. Arthur, Douglas T. Hall and Barbara S. Lawrence (eds.), Handbook of Career Theory. Cambridge: Cambridge University Press. Available at: https://doi. org/10.1017/CBO9780511625459.007.

Daniel, William T. 2015. Career Behaviour and the European Parliament: All Roads Lead Through Brussels? Oxford: Oxford University Press. Available at: https://doi. org/10.1093/acprof:oso/9780198716402.001.0001.

Dowding, Keith and Patrick Dumont. 2009. The Selection of Ministers in Europe: Hiring and Firing. Abingdon: Routledge.

Dowding, Keith and Patrick Dumont. 2015. "Agency Rent, Adverse Selection and Moral Hazard", in Keith Dowding and Patrick Dumont (eds.), The Selection of Ministers around the World. London and New York: Routledge.

Dudzińska, Agnieszka, Corentin Poyet, Olivier Costa and Bernhard Weßels. 2014. "Representational Roles", in Kris Deschouwer and Sam Depauw (eds.), Representing the People. A Survey Among Members of Statewide and Sub-State Parliaments. Oxford: Oxford University Press. Available at: https://doi.org/10.1093/ acprof:oso/9780199684533.003.0002.

Edinger, Michael and Stefan Jahr. 2015. Political Careers in Europe. Career Patterns in Multi-Level Systems. Baden-Baden: Nomos. Available at: https://doi. org/10.5771/9783845239200.

Fettelshoß, Katja. 2009. Politische Eliten und Demokratie. Professionalisierung von Ministern in Mittelosteuropa. Baden-Baden: Nomos Verlag. Available at: https:// doi.org/10.5771/9783845218168.

Fischer, Jörn, Keith Dowding and Patrick Dumont. 2012. "The Duration and Durability of Cabinet Ministers", International Political Science Review, 33 (5): 505519. Available at: https://doi.org/10.1177/0192512112462971.

Fischer, Jörn, André Kaiser, and Ingo Rohlfing. 2006. "The Push and Pull of Ministerial Resignations in Germany, 1969-2005”, West European Politics, 29 (4): 709735. Available at: https://doi.org/10.1080/01402380600842296.

Gaxie, Daniel. 2018. "Political and Social Backgrounds of Political Elites", in Heinrich Best and John Higley (eds.), The Palgrave Handbook of Political Elites. Basings- 
toke: Palgrave Macmillan. Available at: https://doi.org/10.1057/978-1137-51904-7_31.

Gerber, Marius, Anette Wittekind, Gudela Grote and Bruno Staffelbach. 2009. "Exploring Types of Career Orientation. A Latent Class Analysis Approach", Journal of Vocational Behavior, 75 (3): 303-318. Available at: https://doi.org/10.1016/j. jvb.2009.04.003.

Gouglas, Athanassios, Bart Maddens, and Marleen Brans. 2018. "Determinants of Legislative Turnover in Western Europe, 1945-2015", European Journal of Political Research, 57 (3): 637-661. Available at: https://doi.org/10.1111/1475-6765.12246.

Greenstein, Fred I. 1969. Personality and Politics. Problems of Evidence, Inference, and Conceptualization. Chicago: Markham.

Grimaldi, Selena and Michelangelo Vercesi. 2018. "Political Careers in Multi-Level Systems: Regional Chief Executives in Italy, 1970-2015", Regional and Federal Studies, 28 (2): 125-149. Available at: https://doi.org/10.1080/13597566.2017.1407314.

Hall, Richard L. and Bernard Grofman. 2014. "The Committee Assignment Process and the Conditional Nature of Committee Bias", American Political Science Review, 84 (4): 1149-1166. Available at: https://doi.org/10.2307/1963257.

Hall, Richard L. and Robert P. van Houweling. 1995. "Avarice and Ambition in Congress: Representatives' Decisions to Run or Retire from the U.S. House", The American Political Science Review, 89 (1): 121-136. Available at: https://doi. org/10.2307/2083079.

Haslam, S. Alexander, Stephen D. Reicher, and Michael J. Platow. 2011. The New Psychology of Leadership. Identity, Influence and Power. New York: Routledge.

Hazan, Reuven Y. and Gideon Rahat. 2010. Democracy within Parties. Candidate Selection Methods and Their Political Consequences. Oxford: Oxford University Press. Available at: https://doi.org/10.1093/acprof:oso/9780199572540.001.0001.

Herrick, Rebekah and Michael K. Moore. 1993. "Political Ambition's Effect on Legislative Behavior: Schlesinger's Typology Reconsidered and Revised", The Journal of Politics, 55 (3): 765-76. Available at: https://doi.org/10.2307/2132000.

Herzog, Dietrich. 1975. Politische Karrieren. Selektion und Professionalisierung politischer Führungsgruppen. Opladen: Westdeutscher Verlag.

Hibbing, John R. 1993. "The Career Paths of Members of Congress", in Shirley Williams and Edward L. Lascher (eds.), Ambition and Beyond: Career Paths of American Politicians. Berkeley: Institute of Governmental Studies Press.

Hodgson, Geoffrey M. 2007. "Meanings of Methodological Individualism", Journal of Economic Methodology, 14 (2): 211-226. Available at: https://doi. org/10.1080/13501780701394094.

Hodkinson, Phil and Andrew C. Sparkes. 1997. "Careership: A Sociological Theory of Career Decision Making", British Journal of Sociology and Education, 18 (1): 29-44. Available at: https://doi.org/10.1080/0142569970180102.

Hoffmann-Lange, Ursula. 2007. "Methods of Elite Research", in Russel J. Dalton and Hans-Dieter Klingemann (eds.), The Oxford Handbook of Political Behavior. Oxford: Oxford University Press. 
Hubert, John D. and Cecilia Martinez-Gallardo. 2008. "Replacing Cabinet Ministers: Patterns of Ministerial Stability in Parliamentary Democracies", American Political Science Review, 102 (2): 169-180. Available at: https://doi.org/10.1017/ S000305540808012X.

Hudson, Valerie M. 1990. "Birth Order of World Leaders: An Exploratory Analysis of Effects on Personality and Behavior", Political Psychology, 11 (3): 583-601. Available at: https://doi.org/10.2307/3791665.

Jäckle, Sebastian. 2015. "Event-History-Analyse", in Achim Hildebrandt, Sebastian Jäckle, Frieder Wolf and Andreas Heindl (eds.), Methodologie, Methoden, Forschungsdesign. Ein Lehrbuch für fortgeschrittene Studierende der Politikwissenschaft. Wiesbaden: Springer.

Jäckle, Sebastian. 2016. "Pathways to Karlsruhe: A Sequence Analysis of the Careers of German Federal Constitutional Court Judges”, German Politics, 25 (1): 25-53. Available at: https://doi.org/10.1080/09644008.2015.1124266.

Jäckle, Sebastian and Matthew Kerby. 2018. "Temporal Methods in Political Elite Studies", in Heinrich Best and John Highly (eds.), The Palgrave Handbook of Political Elites. Basingstoke: Palgrave Macmillan. Available at: https://doi. org/10.1057/978-1-137-51904-7_10.

Jalalzai, Farida. 2013. Shattered, Cracked, or Firmly Intact? Women and the Executive Glass Ceiling Worldwide. Oxford: Oxford University Press. Available at: https:// doi.org/10.1093/acprof:oso/9780199943531.001.0001.

Jahr, Stefan and Michael Edinger. 2015. "Making Sense of Multi-Level Parliamentary Careers: An Introduction”, in Michael Edinger and Stefan Jahr (eds.), Political Careers in Europe. Career Patterns in Multi-Level Systems. Baden-Baden: Nomos. Available at: https://doi.org/10.5771/9783845239200-9.

Judge, David. 1981. Backbench Specialisation in the House of Commons. London: Heinemann Educational Books.

Jun, Hae-Won and Simon Hix. 2010. "Electoral Systems, Political Career Paths and Legislative Behavior. Evidence from South Korea's Mixed-Member System”, Japanese Journal of Political Science, 11 (02): 153-171. Available at: https://doi. org/10.1017/S1468109910000058.

Krook, Mona L. 2010. "Beyond Supply and Demand: A Feminist-Institutionalist Theory of Candidate Selection”, Political Research Quarterly, 63 (4): 707-720. Available at: https://doi.org/10.1177/1065912909336275.

Lasswell, Harold D. 1948. Power and Personality. New York: The Norton Library.

Lawless, Jennifer L. 2012. Becoming a Candidate: Political Ambition and the Decision to Run for Office. Cambridge: Cambridge University Press.

MacKenzie, Scott A. 2015. "Life before Congress: Using Precongressional Experience to Assess Competing Explanations for Political Professionalism", The Journal of Politics, 77 (2): 505-518. Available at: https://doi.org/10.1086/680042.

Maestas, Cherie. 2003. "The Incentives to Listen: Progressive Ambition, Resources, and Opinion Monitoring among State Legislators", Journal of Politics, 65 (2): 439-456. Available at: https://doi.org/10.1111/1468-2508.t01-3-00008. 
Martocchia Diodati, Nicola and Luca Verzichelli. 2017. "Changing Patterns of Ministerial Circulation. The Italian Case in a Long-Term Perspective", West European Politics, 40 (6): 1352-1372. Available at: https://doi.org/10.1080/01402382.201 7.1318254 .

Mughan, Anthony, Janet Box-Steffensmeier and Roger Scully. 1997. "Mapping Legislative Socialisation”, European Journal of Political Research, 32 (1), 93-106. Available at: https://doi.org/10.1111/1475-6765.00333.

Müller-Rommel, Ferdinand and Michelangelo Vercesi. 2017. "Prime Ministerial Careers in the European Union. Does Gender Make a Difference?”, European Politics and Society, 18 (2): 245-262. Available at: https://doi.org/10.1080/23745 118.2016.1225655.

Nicholls, Keith. 1991. "The Dynamics of National Executive Service. Ambition Theory and the Careers of Presidential Cabinet Members", Western Political Quarterly, 44 (1): 149-172. Available at: https://doi.org/10.2307/448752.

Norris, Pippa. 2006. "Recruitment", in Richard S. Katz and William Crotty (eds.), The Handbook on Political Parties. London: Sage Publications.

Norris, Pippa and Joni Lovenduski. 1993. "'If Only More Candidates Came Forward': Supply-Side Explanations of Candidate Selection in Britain”, British Journal of Political Science, 23 (3): 373-408. Available at: https://doi.org/10.1017/ S0007123400006657.

Norris, Pippa and Joni Lovenduski. 1995. Political Recruitment. Gender, Race and Class in the British Parliament. Cambridge: Cambridge University Press.

Öhberg, Patrik. 2017. Ambitious Politicians. The Implications of Career Ambition in Representative Democracy. Lawrence: University Press of Kansas. Available at: https://doi.org/10.2307/j.ctt1 nxqpm1.

Ohmura, Tamaki, Stefanie Bailer, Peter Meißner, and Peter Selb. 2018. "Party Animals, Career Changers and Other Pathways into Parliament", West European Politics, 41 (1): 169-195. Available at: https://doi.org/10.1080/01402382.2017.1323 485.

Pansardi, Pamela and Michelangelo Vercesi. 2017. "Party Gate-Keeping and Women's Appointment to Parliamentary Committees: Evidence from the Italian Case", Parliamentary Affairs, 70 (1): 62-83. Available at: https://doi.org/10.1093/pa/ gsv066.

Peters, B. Guy. 2010. The Politics of Bureaucracy. An Introduction to Comparative Public Administration. Sixth Edition. Abingdon: Routledge.

Pfeffer, Jeffrey. 1989. "A Political Perspective on Careers: Interests, Networks, and Environments", in Michael B. Arthur, Douglas T. Hall and Barbara S. Lawrence (eds.), Handbook of Career Theory. Cambridge: Cambridge University Press. Available at: https://doi.org/10.1017/CBO9780511625459.021.

Pilet, Jean-Benoit, Filippo Tronconi, O-ate, Pablo and Luca Verzichelli. 2014. "Career Patterns in Multilevel Systems", in Kris Deschouwer and Sam Depauw (eds.), Representing the People. A Survey Among Members of Statewide and Sub-State Parliaments. Oxford: Oxford University Press. 
Post, Jerrold M. 2013. "Psychobiography. 'The Child Is Father of the Man”, in Leonie Huddy, David O. Sears and Jack S. Levy (eds.), The Oxford Handbook of Political Psychology. Oxford: Oxford University Press.

Putnam, Robert D. 1976. The Comparative Study of Political Elites. Englewood Cliffs: Prentice-Hall.

Real-Dato, José and Francisco Alarcón-González. 2012. The Significance of the European Parliament in Political Careers: Evidence from the Careers of Spanish MEPs (1986-2010). Presented at the General Conference of the ECPR Standing Group on Parliaments, Dublin, 24-27 June.

Samuels, David and Matthew S. Shugart. 2010. Presidents, Parties, and Prime Ministers. How the Separation of Powers Affects Party Organization and Behavior. Cambridge: Cambridge University Press. Available at: https://doi.org/10.1017/ CBO9780511780882.

Schafer, Mark. 2014. "At-A-Distance Analysis", in Rod A. W. Rhodes and Paul 't Hart (eds.), The Oxford Handbook of Political Leadership. Oxford: Oxford University Press.

Schlesinger, Joseph A. 1966. Ambition and Politics. Political Careers in the United States. Chicago: Rand McNally and Company.

Scully, Roger. 2005. Becoming Europeans? Attitudes, Behaviour, and Socialization in the European Parliament. Oxford: Oxford University Press. Available at: https:// doi.org/10.1093/0199284326.001.0001.

Searing, Donald D. 1991. "Roles, Rules, and Rationality in the New Institutionalism”, American Political Science Review, 85 (4): 1239-1260. Available at: https:// doi.org/10.2307/1963944.

Searing, Donald D., Joel J. Schwartz and Alden E. Lind. 1973. "The Structuring Principle: Political Socialization and Belief Systems”, American Political Science Review, 67 (2): 415-432. Available at: https://doi.org/10.2307/1958774.

Siavelis, Peter and Scott Morgenstern. 2008. Pathways to Power. Political Recruitment and Candidate Selection in Latin America. University Park: The Pennsylvania State University Press.

Sieberer, Ulrich and Wolfgang C. Müller. 2017. "Aiming Higher: The Consequences of Progressive Ambition among MPs in European Parliaments", European Political Science Review, 9 (1): 27-50. Available at: https://doi.org/10.1017/ S1755773915000260.

Stolz, Klaus. 2001. "The Political Class and Regional Institution-Building: A Conceptual Framework", Regional and Federal Studies, 11 (1): 80-100. Available at: https://doi.org/10.1080/714004678.

Stolz, Klaus. 2003. "Moving Up, Moving Down: Political Careers across Territorial Levels”, European Journal of Political Research, 42 (2): 223-248. Available at: https://doi.org/10.1111/1475-6765.00081.

Stolz, Klaus. 2010. Towards a Regional Political Class? Professional Politicians and Regional Institutions in Catalonia and Scotland. Manchester and New York: Manchester University Press. Available at: https://doi.org/10.7228/manchester/9780 719079795.001 .0001 . 
Stolz, Klaus. 2015. "Legislative Careers in a Multi-Level Europe", in Michael Edinger and Stefan Jahr (eds.), Political Careers in Europe. Career Patterns in Multi-Level Systems. Baden-Baden: Nomos. Available at: https://doi.org/10.5771/9783845239200-179.

Stolz, Klaus and Jörn Fischer. 2014. "Post-Cabinet Careers of Regional Ministers in Germany, 1990-2011”, German Politics, 23 (3): 157-173. Available at: https:// doi.org/10.1080/09644008.2014.949683.

Thurber, James A. 1976. "The Impact of Party Recruitment Activity upon Legislative Role Orientations: A Path Analysis”, Legislative Studies Quarterly, 1 (4): 533-549. Available at: https://doi.org/10.2307/439660.

Verzichelli, Luca. 2018. "Elite Circulation and Stability", in Heinrich Best and John Higley (eds.), The Palgrave Handbook of Political Elites. Basingstoke: Palgrave Macmillan. Available at: https://doi.org/10.1057/978-1-137-51904-7_36.

Vommaro, Gabriel and Marian Gené (eds.) 2018. Las elites politicas en el Sur. Un estado de la cuestión de los estudios sobra Argentina, Brasil y Chile. Los Polvorines: Ediciones UNGS.

Walter, James. 2014. "Biographical Analysis", in Rod A. W. Rhodes and Paul 't Hart (eds.), The Oxford Handbook of Political Leadership. Oxford: Oxford University Press.

Winter, David G. 2013. "Personality Profiles of Political Elites", in Leonie Huddy, David O. Sears and Jack S. Levy (eds.), The Oxford Handbook of Political Psycho$\log y .2^{\text {nd }}$ ed. Oxford: Oxford University Press.

Zanzi, Alberto, Michael B. Arthur and Boas Shamir. 1991. "The Relationships Between Career Concerns and Political Tactics in Organizations", Journal of Organizational Behavior, 22 (3): 219-233. Available at: https://doi.org/10.1002/ job.4030120305.

Submitted for evaluation: 5 April 2018.

Accepted for publication: 5 September 2018.

\section{MICHELANGELO VERCESI}

michelangelo.vercesi@leuphana.de

Research Associate at the Center for the Study of Democracy and the Institute of Political Science of Leuphana University in Lüneburg (Germany). He is member of the executive committee of the IPSA/ISA Committee on Political Sociology. Previously, he was Adjunct Lecturer at the University of Milan and worked with the Einaudi Center for Investigation and Documentary Research (Turin, Italy). He holds a PhD in Political Science from the University of Pavia (Italy), where he also was teaching assistant. He held research positions in Germany and in Austria. He has published several book chapters and articles in peer-reviewed journal, such as Regional and Federal Studies, Parliamentary Affairs, Journal of Modern Italian Studies, Politics and Policy, European Politics and Society and Government and Opposition. 